\title{
A Meso-levels Critical Discourse Analysis of the Movie Rudy Habibie
}

\author{
Goziyah \\ Postgraduate Program, Universitas Negeri Jakarta, Indonesia; \\ Muhammadiyah University of Tangerang, Indonesia \\ Dadang Sunendar \\ Indonesia University of Education, Indonesia \\ Yumna Rasyid \\ Postgraduate Program, Universitas Negeri Jakarta, Indonesia
}

\begin{abstract}
Movie and discourse have been an academic concern. Based on the theoretical framework of Fairclough concept (1995), this study attempts to make a meso-level critical discourse analysis of a local movie, Rudy Habibie (2016). It explores how the discursive is formed and legitimized in the process of production, distribution, and consumption by the representation of the movie Rudy Habibie. It validates the effectiveness of CDA as a tool to reveal the relationship between language and ideology. It proves that Fairclough's framework can be applied in the movie discursive study. Pratically it draws the attention to the ideologies embedded in movie discourse and encourages to improve the critical thinking. The findings described the various behaviors taken from the movie Rudy Habibie which are aimed to reveal stereotypes, presuppositions, hegemony, power and ideological stances. As the consequences, this movie became the best selling movie in 2016. The presented ideology delivered the audience through the story of the movie as the result of the text production, distribution, and consumption. The representation contributes to the construction of social power. Furthermore, the research believed having implications for language teaching, especially in CDA subject. Toward the applying of the CDA approach in the course, the student will be able to achieve the understanding of the writer's style, finding meaning and reasons for particular stylistic choices.
\end{abstract}

Index Terms - critical discourse analysis, discursive practice, meso-level framework, text production, text distribution, text consumption

\section{INTRODUCTION}

Discourse can be seen as a set of meanings, metaphors, representations, images, stories, reports and so on which in some way produce certain versions of events together (Baker \& Ellece, 2011). Chen (2016) argues that discourse is socially shaped and socially constitutive. Any discursive event is seen as being simultaneously a piece of text, an instance of discursive practice, and an instance of social practice (Fairclough, 1992). There may be various different discourses with a different story about the world and in different ways in representing the world. As the qualitative analytical approach, critical discourse analysis (CDA) critically describes, interprets, and explains the ways in which discourses construct, maintain, and legitimize social imbalance. CDA studies the social power in a social context, including political by talking not only about semantic meanings of the discourse. The CDA highlights the substantively linguistic and discursive nature of social relations of power in contemporary societies. In defining CDA, Fairclough (1995) mentioned three central constructs, (1) Text and the study of 'texture'. It is related to linguistics, for example by looking at the vocabulary, semantics, and sentence, as well as coherence and cohesiveness, and how these units form a metaphor; (2) Discoursal practices and the concept 'orders of discourse'. It is a dimension related to the process of production and consumption of text, like work patterns, work charts, and routines when generating news.; and (3) sociocultural practices and the concept of 'culture'. It related to context outside the text; such as the context of the situation or the context of the media in relation to a particular society or political culture. CDA provides theories and methods that can be used to conduct empirical studies of the relationships between discourse and social, including cultural development in different social domains. The purpose of CDA is to explain the linguistic dimensions of the social and cultural phenomenon and the process of change in modernity (Jogensen\& Phillips, 2007, p. 15).

Discursive practice requires the interpretation of discursive process which includes the aspects of production, distribution, and consumption of the text. In the production stage, the in-depth analysis was done for the whole involved parties in order to know the ways in producing the text. In the text distribution stage, the used media were analyzed in order to describe how media distribute the text, whether through the printed or electronic media. It should be examined to know the impact on the discourse effect because every media has different advantages and disadvantages. In the text 
consumption stage, the targeted text receivers were analyzed to know who consumes the media because each media has a different market share.

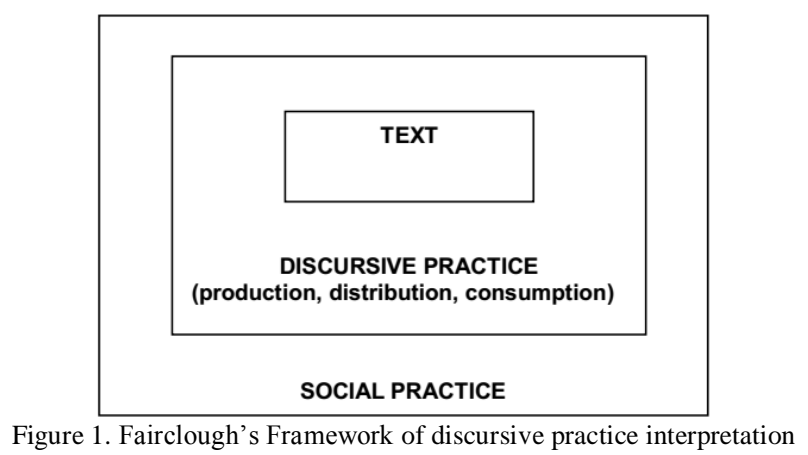

In CDA, the language context can be seen as a tool used for certain purposes and practices including ideological practice and power. It can be seen as a central concept of the CDA. Raymond William in Fiske (1990) described ideology in 3 domains; 1) a belief system by a particular group or class. This definition is used in the realm of psychology that views psychology as an attitude that is formed and coherently organized; 2) a created belief system that can be countered with knowledge. In this sense, ideology is a created category and a false consciousness when the dominant group uses it to dominate other non-dominant groups; 3) the general process of meanings and ideas production. The text reflects the ideology through the language and it can influence the way people thinking. Discourse can be seen as a medium to persuade people. In his research findings, Chen (2016) argues that the linguistic differences involving such areas as lexical classification, process types, and discourse representation can be traced back to the personal ideological orientations. It can't be explained without taking the different ideological orientations and power relations into consideration. Basically, language is shaped by power and ideology. Ideologies reside in discourse. Ideology and power are primarily discursive in nature. Ideology is primarily established, sustained and challenged.

Discourse covers not only written and spoken languages but includes visual images (Jorgensen\& Phillips, 2002). It is possible to be applied through considering the special characteristics of visual semiotics and the relationship between language and image. As one of the visual images, the movie can be seen as a product of the human culture that represents the values of the views of certain groups of people, including their spirit and ideologies. As a cultural artwork and cinematography that can be demonstrated with or without sound, Trianton (2013) argues that movie is a mass communication media that carries messages containing important ideas submitted to the public in the form of spectacle. The movie can be described as life images that contain stories. Furthermore, Mcluhan (1997) argues that a movie is an experience in non-verbal form like photography including a form of statement without syntax. As a media, the movie certainly represents the views held by a particular group, including the ideology and ideas brought by the group. This becomes very essential because the movie conveys the ideology subtly and has the element of coercion.

Rudy Habibie is 2016 Indonesian drama movie about a visionary youth story: Rudy Habibie before he was known as a technocrat and the $3^{\text {rd }}$ Republic of Indonesia president, B.J. Habibie. This movie received a positive response from the public and shown by its' position on the three best-selling 2016 Indonesian movie list with two million viewers. In 2016 , Rudy Habibibie the movie got some awards in Bandung film festival for, (1) praised film category award; (2) the praised actress award by Chelsea Islan; and (3) the supported actress award by Indah Permatasari. As a media, this movie was intended to convey an ideology that can affect the viewers through written and spoken languages including the visual images. Media can be seen a tool to deliver the ideology (Zhang, 2014; Mayasari, et. all., 2013; Vahid \& Esmae'li, 2012; Kaur, et.al., 2013; Iqbal, et. all., 2014a, 2014b). By the end, the finding of this research can be used as the alternative of attractive teaching media in critical discourse analysis course.

\section{Methodology}

The research was begun with preliminary study through the observation and literature study about CDA, discursive practice, the movie Rudy Habibie, movie media, including ideology. Based on the preliminary research, topics and research problems were formulated. The developed theory is the CDA framing theory by Fairclough (1997). The research data are taken from text production, text distribution and text consumption of the movie Rudy Habibie (2016). The collected data was described, analyzed, interpreted and explained as a part of the qualitative method (Mulyana, 2001; Muhadjir, 2000). Fraenkel and Wallen (1993) strengthened by describing that qualitative research is considered to describe the research object completely and comprehensively. Qualitative research methods are interpreted as research that produces qualitative data in the form of written or spoken words of the people or observed behaviors (Moleong, 2002). 
TABLE 1.

THE PROCEDURE OF DATA ANALYSIS

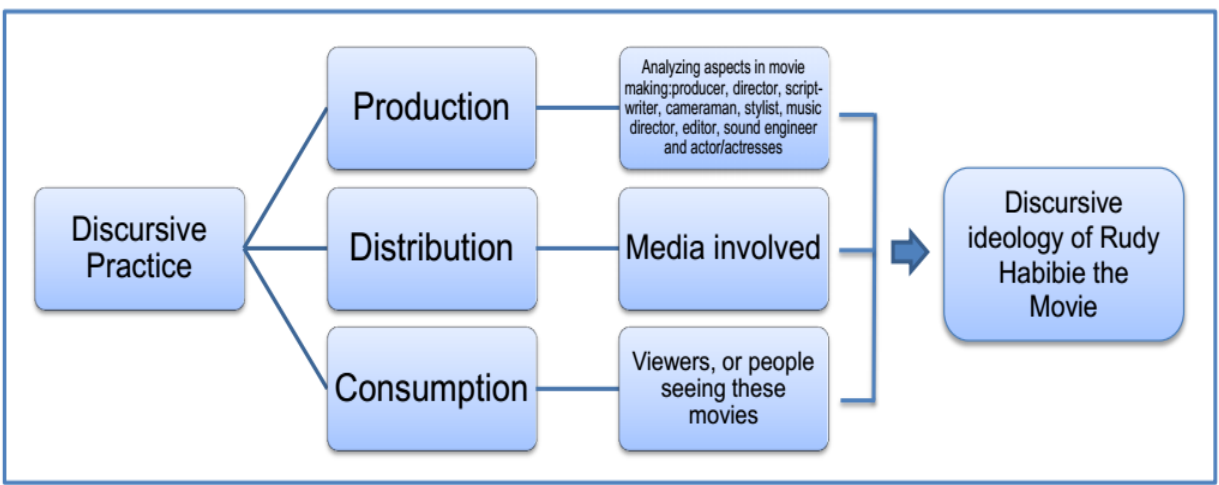

\section{RESULT AND ANALYSIS}

Based on data analysis taken from the movie Rudy Habibie (2016) through meso-levels analysis, the findings and discussion described in the below divided in the text of production, distribution, and consumption.

\section{Text Production}

In this part, to show the elements related to production process analyzed and interpreted. The below table presents the person in charge involved in the production process of the movie Rudy Habibie.

TABLE 2.

Text PRoduction

\begin{tabular}{|c|c|c|c|}
\hline No & Position & Person in Charge & Analysis Results \\
\hline 1 & Production house & MD Entertainment & $\begin{array}{l}\text { Multi Dimensia Entertainment (or MD Entertainment) is a production house in } \\
\text { Indonesia. It was founded by Dhamoo Punjabi and Manoj Punjabi, after leaving } \\
\text { Multivision Plus on December 7, 2002. During the year of } 2005 \text { up to } 2016,22 \\
\text { awards had been obtained, including many prestigious awards such as Panasonic } \\
\text { Awards, SCTV Awards, Indonesian Movie Awards and Yahoo OMG Awards. }\end{array}$ \\
\hline 2 & Producer & Manoj Punjabi & $\begin{array}{l}\text { He is a film and television producer and the owner of the biggest Indonesia } \\
\text { production house. In } 2007 \text {, He produced } 11 \text { movie title with a large audience. One } \\
\text { of his movie, Danur: I can see ghost, got an award from the Indonesian World } \\
\text { Records Museum as a horror movie with the highest number of viewers in just six } \\
\text { days, which is } 1,196,583 \text { viewers. }\end{array}$ \\
\hline 3 & Director & Hanung Bramantyo & $\begin{array}{l}\text { He is an Indonesian director. In } 2005 \text { Indonesia film festival, he won the best } \\
\text { director award through his directed movie, Brownies. He was also nominated as } \\
\text { best director in the independent movie, Sayekti and Hanafi. In } 2007 \text { Indonesian } \\
\text { film festival, he won the best director through Get Married Movie. He did not finish } \\
\text { his study at the faculty of economics in Indonesia Islamic University and in } \\
\text { Yogyakarta Educational and Teaching Institute. He continued his study in film } \\
\text { faculty department of Jakarta Art Institute. Several of his movies became } \\
\text { controversial for how they deal with religion. }\end{array}$ \\
\hline \multirow[t]{2}{*}{4} & \multirow[t]{2}{*}{ Script writer } & Gina S. Noer & $\begin{array}{l}\text { She is an Indonesia creativepreneur; co-founder and chief editor at PlotPoint } \\
\text { Publishing \& Workshop; and also known as screen writer for film and television.In } \\
\text { 2008, she wrote the screenplay of Ayat-Ayat Cinta the movie which was a } \\
\text { successful record-breaking audience of } 3.5 \text { million viewers. } \\
\text { At the } 2009 \text { Indonesian Film Festival she was nominated as the Best Adaptation } \\
\text { Scenario through Perempuan Berkalung Sorban the movie. In addition to its } \\
\text { commercial success, the film also attracted controversy. } \\
\text { At the } 2010 \text { Indonesian Film Festival, she was nominated for the Best Screenplay } \\
\text { for Hari untuk Amanda the movie. } \\
\text { In } 2012 \text {, she was co-writer for screenplay Habibie \&Ainun the movie based on the } \\
\text { life and love story of former third Indonesian president Bacharuddin Jusuf Habibie } \\
\text { and Hasri Ainun Besari. The film managed to break the record number of } 2,000,000 \\
\text { viewers within two weeks of airing. The film reached } 4,488,999 \text { viewers. } \\
\text { On December } 7,2013 \text {, together with Ifan Adriansyah Ismail won the Best } \\
\text { Screenplay Writer trophy at the } 2013 \text { Indonesian Film Festival for Habibie \&Ainun } \\
\text { the movie. } \\
\text { She graduated from Universitas Indonesia, majoring in broadcasting and mass- } \\
\text { communication. }\end{array}$ \\
\hline & & Hanung Bramantyo & Same as the above information \\
\hline 5 & Cameraman & Ipung Rachmat Syaiful & $\begin{array}{l}\text { In } 2015 \text { Bandung Film Festival, he was selected as the commendable camera artist } \\
\text { in Guru Bangsa: Tjokroaminoto the movie. }\end{array}$ \\
\hline 6 & Art director & Allan Sebastian & $\begin{array}{l}\text { At the } 2015 \text { Indonesian Film Festival, he won the Best Art Director category } \\
\text { through Guru Bangsa: Tjokroaminoto the movie. }\end{array}$ \\
\hline
\end{tabular}




\begin{tabular}{|c|c|c|c|}
\hline 7 & Editor & Wawan I. Wibowo & $\begin{array}{l}\text { He won the Best Editor Award in } 2009 \text { Indonesian Film Festival for Pintu } \\
\text { Terlarang the movie. In 2016, he won The Best Editor in Maya Award for Aisyah: } \\
\text { Biarkan Kami Bersaudara the movie. For Citra Award, in 2016, he won it for My } \\
\text { Stupid Bos the movie, in } 2014 \text { for Soekarno the movie and in } 2009 \text { for Pintu } \\
\text { Terlarang the movie. }\end{array}$ \\
\hline 8 & Music editor & Tya Subiakto & $\begin{array}{l}\text { She is a composer, conductor, music director and film director. She won the praised } \\
\text { music director in } 2008 \text { Bandung Film Festival for Ayat-Ayat Cinta the movie and in } \\
2011 \\
\text { Bandung Film Festival for Sang Pencerah the movie. }\end{array}$ \\
\hline 9 & Sound editor & KhikmawanSantosa & $\begin{array}{l}\text { In 2004, he began his first career as a voice recorder and sound editor in Virgin and } \\
\text { Brownies the movie. In 2009, he won the Best Sound Editor award in Indonesia } \\
\text { Film Festival Ruma Maida the movie. } \\
\text { In } 2013 \text {, he won Citra award as the Best Sound Editor for Sang Kyai the movie. } \\
\text { In } 2017 \text { Indonesia Film Festival, he won four nominations in the Best Sound Editor } \\
\text { category through Kartini the movie, Pengabdi Setan the movie, Cek Toko Sebelah } \\
\text { the movie and Critical Eleven the movie. }\end{array}$ \\
\hline 10 & Sound designer & Chris David & $\begin{array}{l}\text { Christopher Sinclair David is a sound designer who became the mainstay of } \\
\text { Hollywood movies (Face Off, Alien 3, American Pie, The Expendables and } \\
\text { Olympus Has Fallen). He received an Oscar nomination for the film Legend of The } \\
\text { Fall in } 1994 .\end{array}$ \\
\hline \multirow{11}{*}{11} & \multirow{11}{*}{$\begin{array}{l}\text { Actors and } \\
\text { actresses }\end{array}$} & $\begin{array}{l}\text { Reza Rahardian as } \\
\text { Rudy Habibie }\end{array}$ & $\begin{array}{l}\text { In 2009, Reza won Citra award for the best supporting actor in Perempuan } \\
\text { Berkalung Sorban the movie. } \\
\text { In the following year, he won the Citra award for the best actor in } 3 \text { Hati, Dua } \\
\text { Dunia the movie. } \\
\text { In } 2013 \text {, Reza won IMA Gold Screen Cup for the top favorite actor in } \\
\text { Habibie \&Ainun the movie. }\end{array}$ \\
\hline & & $\begin{array}{l}\text { Chelsea Islan as Illona } \\
\text { Ianovska }\end{array}$ & $\begin{array}{l}\text { Chelsea has had a basis in acting through the best theater stage. She has been } \\
\text { awarded for the best actress nominations for Di Balik } 98 \text { the movie in } 2015 \text { and the } \\
\text { movie Rudy Habibie in } 2016 \text {. }\end{array}$ \\
\hline & & $\begin{array}{l}\text { Ernest Prakarsa as } \\
\text { Liem Keng Kie }\end{array}$ & $\begin{array}{l}\text { He is an Indonesian comedian, writer, and actor. He became popular after receiving } \\
\text { the } 3^{\text {rd }} \text { place in Stand Up Comedy Indonesia in 2011. In 2016, He won an award of } \\
\text { the best scenario writer in Indonesia Box Office Movie Awards for Ngenest the } \\
\text { movie. }\end{array}$ \\
\hline & & $\begin{array}{l}\text { Boris Bokir as Poltak } \\
\text { Hasibuan }\end{array}$ & $\begin{array}{l}\text { He is a comedian and known since becoming one of the participants at Stand Up } \\
\text { Comedy Indonesia in Kompas TV in } 2012 .\end{array}$ \\
\hline & & $\begin{array}{l}\text { Verdy Solaiman as } \\
\text { Romo Mangun }\end{array}$ & $\begin{array}{l}\text { In } 2004 \text { he studied acting in Sakti Aktor Studio School of Acting. He engaged in } \\
\text { theatrical performances of off-broadway works and staging Mass Appeal from Bill } \\
\text { C. Davis. He is an actor and creative director of promoting some movies. He was } \\
\text { nominated as the best supporting actor in } 2009 \text { Indonesia Film Festival, } 2010 \\
\text { Indonesia Movie Award and } 2013 \text { Indonesia Movie Award. }\end{array}$ \\
\hline & & $\begin{array}{l}\text { Millane Fernandez as } \\
\text { Sofia }\end{array}$ & $\begin{array}{l}\text { She is an actress and a singer. She has experiences in MTV VJ Hunt. The movie } \\
\text { Rudy Habibie is her } 2^{\text {nd }} \text { experience in movie acting. }\end{array}$ \\
\hline & & $\begin{array}{l}\text { Pandji Pragiwaksono } \\
\text { as Peter Manumasa }\end{array}$ & $\begin{array}{l}\text { He is an actor, radio broadcaster, television presenter, book author, rap singer, and } \\
\text { stand up comedian. }\end{array}$ \\
\hline & & $\begin{array}{l}\text { Indah Permatasari as } \\
\text { Ayu (Solo sultan's } \\
\text { daughter) }\end{array}$ & $\begin{array}{l}\text { She is an actress and model. She won the praised supporting actress in } 2016 \\
\text { Bandung Film Festival in Rudy Habibie the movie. }\end{array}$ \\
\hline & & $\begin{array}{l}\text { Bagas Luhur Pribadi } \\
\text { as Sugeng (Ayu's } \\
\text { assistant) }\end{array}$ & He is an actor with the first debut in Rudy Habibie the movie. \\
\hline & & $\begin{array}{l}\text { Dian Nitami as Mother } \\
\text { of Rudy Habibie }\end{array}$ & $\begin{array}{l}\text { She is an actress with many experiences in acting from 1986. She was nominated as } \\
\text { the best actress in } 1991 \text { Indonesia Film Festival. }\end{array}$ \\
\hline & & $\begin{array}{l}\text { Donny Damara as } \\
\text { Father of Rudy } \\
\text { Habibie }\end{array}$ & $\begin{array}{l}\text { He is an actor with many experiences in acting from 1988. He won: 1) the best } \\
\text { actor in } 2012 \text { Asian Film Award for Lovely Man the movie; 2) the best actor in } \\
2012 \text { Indonesia Movie Award for Lovely Man the movie; 3) the best actor in } 2012 \\
\text { Indonesia Film Festival for Lovely Man the movie; 4) the best actor in } 2012 \text { Maya } \\
\text { Award for Lovely Man the movie; 5) Chosen Actor Award in } 2012 \text { Balinale } \\
\text { International Film Festival for Lovely Man the movie; and 6) Supported Actor in } \\
2015 \text { Maya Award for 2014, Siapa di Atas Presiden the movie. }\end{array}$ \\
\hline \multirow{2}{*}{12} & \multirow{2}{*}{ Setting } & Indonesia & Taken in Yogyakarta and Cisarua, Bogor \\
\hline & & German & $80 \%$ was located in German \\
\hline
\end{tabular}

The table informed that Rudy Habibie the movie, a prequel of Habibie \& Ainun the movie, was produced by Manoj Punjabi from MD Entertainment. MD Entertainment is known as one of the biggest production house in Indonesia that has a good image in making many successful and qualified movie. It can be seen from the various awards achieved. Not only about the quality, they know how to make the best selling movie.

As a producer, Manoj having self-confidence that Rudy Habibie the movie will be a success as the previous one, Habibie \& Ainun. He realized and believed that Habibie is an inspiring figure that can attract many viewers. It strengthened with the date of the movie premiere that coinciding with BJ. Habibie $80^{\text {th }}$ birthday on June $25^{\text {th }}, 2016$. Not only about Habibie figure, as a producer and a key person, Manoj totally understood what he should do to create his desire. He chose great people in the field of film to engage in producing this movie. Hanung Bramantyo was elected to 
direct this movie. People know and believe his quality in directing a movie. He is one of the best Indonesian movie directors who achieved many rewards for his movie creation. Hanung is known for having idealism in doing his job. Hanung argued that Rudy Habibie the movie is a business-oriented product. They produced the movie by considering the things that can attract people to watch, like the romance story between Rudy and a Polish woman, Ilona, in German. Hanung realized that the lack of this movie is not shown the Ainun figure, in fact, this movie is a prequel of the previous movie, Habibie \& Ainun.

Not only being a movie director, together with Gina S. Noer, Hanung prepared the script of Rudy Habibie the movie. The script adapted from a novel written by Gina, Rudy: Kisah Masa Muda Sang Visioner, and Hanung developed the story by considering market demand. This movie is fictional but with historical background. It created only "based on inspiring true story" and not "the true story". Some scenes seem excessive and too dramatized. In addition, the original soundtrack, Mencari Cinta Sejati by Cakra Khan, strengthen the romantic sense of the story. Pradeep (2016) stated that the songs are the other domain of doing CDA, it carries the many aspects of everyday life which are highly complex in the concern of the meaning-making process. Melly Goeslaw and Anto Hoed as the songwriter stated that it was not easy to create the song because they tried to compose the song to be felt as young Habibie in finding his true love. The song was more special because of the process of mastering performed by Marks Sherry at Outburst Studio, Scotland.

In the process of movie making, Manoj tried to maximize the whole thing. In order to get the quality of the movie sound, the sound mixing was done in Hollywood with Christopher Sinclair David, sound designer of The Expendables, Olympus Has Fallen, Face Off, Alien 3, American Pie who has received an Oscar nomination for the film Legend of The Fall (1994). Every scene in this movie has a deep soul and thrilling.

The actors and the actresses who involved in Rudy Habibie the movie are chosen by not only considering the quality but also by considering the audience's attraction. Reza Rahadian was believed to be the right figure as the main character of this movie. He was considered successful to portray Habibie figure. The involvement of Chelsea Islan strengthens the movie attraction. As a young actress, she has a very good star quality that comes not only from her performance and behavior but also from her experience of playing theater. Another interesting thing in this movie is the involvement of three famous Indonesian comics, Ernest Prakarsa, Boris Bokir, and Pandji Pragiwaksono. Hanung tried to feature the comedy side of the movie, but in this movie, he challenged them to act in the biopic or biographical motion picture movie. Other casts strengthen this movie through each character, including Dian Nitami and Dony Damara who have many experiences and achievements in the movie business.

The movie maker gave the attractive visual images by the setting composition, choreography as well as the European fashion used by the cast, especially Ilona. In addition to setting the location, composition, and angle of shooting, the property was able to bring the atmosphere into the past with a setting in Germany. Eighty percent of movie setting taken in Germany directly with local movie crews and the rest taken in Indonesia. The setting of every scene in this movie was complete. The cameramen and the art director having success in describing the nature of the village, the war, the family values, the social atmosphere, including the landscape of Germany complete with different geography, social life, work professionalism, struggle against challenge, educational life, romance, students' movement in Europe and diversity in frame of nationalism to mutual tolerance in respecting the worship.

\section{Text Distribution}

In the text distribution stage, the data showed that MD Pictures having good strategy and commitment by allocating the promotion budget around four to fifteen billion rupiahs. Manoj declared that sixty percent of the budget allocated in digital promotion and forty percent in the conventional. He believed that the promotion should be done in smart ways through various media (television, newspaper, magazine, radio, twitter, Instagram, youtube channel, facebook, and posters). One of Germany's national newspapers, Sachsische Zeitung, carried the news concerning with Rudy Habibie the movie.

To support the distribution, many programs had been designed attractively like a talk show, trailer including meet and greet. When the movie premiere, the producers invited many state officials to watch together and asked them to give testimonials related to Rudy Habibie the movie. Indonesian President, Jokowi, together with the vice president, Jusuf Kalla, and the ministers attended the premiere, including the $6^{\text {th }}$ Indonesia President, Susilo Bambang Yudhoyono.

\section{Text Consumption}

As a media in discursive practice, a movie has the target audience as a product consumer. The data showed us that two million people have watched Rudy Habibie the movie, although Manoj, as the producer, has ambitions for Rudy Habibie the movie to be watched by 10 million people. In fact, Rudy Habibie the movie was in the third position of a best-selling movie in 2016. Besides in Indonesia, the movie had been shown in Malaysia.

\section{DISCUSSIONS AND CONCLUSION}

The above findings describe the discursive practice taken from Rudy Habibie the movie as a media. Media is an explicit domain and public is exposed to various ideologies which influence and blindfold their mind as a certain ideology is enforced on them in their daily life (Ramanathan \& Hoon, 2015). A movie can be seen as a text. Fairclough (1992) strengthen by describing that any discursive event is seen as being simultaneously a piece of text, an instance of discursive practice, and an instance of social practice. Three dimensions of discursive practice cover production, distribution, and consumption that taken from Rudy Habibie the movie produced the ideology. 
The data showed that the movie maker proposed the ideology through Rudy Habibie the movie, not only about the story but also through the production process, the way they distribute the text and the consumption of the viewers. The moviemaker can be seen as the dominant group that try to influence the nondominant one. Mahboob and Paltridge (2013) proclaimed that it is crucial to examine the enactment of power and comprehend the means by which power is exercised by the domination group upon the oppressed. Rudy Habibie movie maker attempted to make the people believe that they must watch the movie because of the quality that produced by the qualified team. To achieve the goal, any propaganda as a part of the distribution stage had been done through various media. The used media reflected the targeted the audience. Manoj is really an expert in optimizing the media use.

The involvement of many good actors, a good team and many state officials as the important people in this country became a strength in distributing this movie as a product, and Manoj truly understands that. The figure of Reza Rahadian and Chelsea Islan is the attraction of the movie. In addition, the testimony from many important people like Jokowi, Jusuf Kalla, Susilo Bambang Yudhoyono, strengthen the movie distribution. The influence of those people made the audience believe in the quality of the movie. The figure of Habibie became the brand image of the movie. The story describing the figure of Rudy as a person who is genius, persistent, passionate, and optimistic.

In making this movie, the producer considered of being a success, to be watched by all ages, and to become the inspired movie. As the consequences, this movie became the best selling movie in 2016 as the prediction of the producer. The presented ideology delivered the audience through the story of the movie as the result of the text production, distribution, and consumption.

The research believed having implications for language teaching, especially in CDA subject. Toward the applying of the CDA approach in the course, the student should be able to achieve the understanding of the writer's style, finding meaning and reasons for particular stylistic choices (Lawson, 2008). Clark and Ivanic (1999) strengthen by stating that the introduction of CDA into the classroom would boost the development of language consciousness, giving students more control over their own use of language, as well as a greater understanding of how they are reflected in the language use of others. Lawson (2008) added by stating that CDA also has a value in encouraging students to challenge texts in their native language. In line with those statements, the researcher suggests to the teacher for being able to find any discourse material or media that suit with the learning goal and students' characteristics.

This study has shown that movie plays a significant role in the ideology production over the social context. It was found that this study has applied CDA to investigate the discursivity of text including the interaction and social context in order to explore the relationship between language and ideology and to examine how dominating ideologies oppress the less powerful through Rudy Habibie the movie. The findings described the various behaviors taken from Rudy Habibie the movie which is aimed to reveal stereotypes, presuppositions, hegemony, power and ideological stances. In conclusion, the representation of social context determines the production of discourse while discourse contributes to the construction of social power. These findings expected to contribute to the existing knowledge of CDA research to increase awareness among movie discourse researchers who aspire to carry out CDA studies. In addition, the research finding can be considered by the teacher to be used as a teaching source in the CDA course.

\section{REFERENCES}

[1] Baker, Paul \& Ellece, Sibonile. (2011). Key terms in discourse analysis. London: Continuum International Publishing Grup.

[2] Chen, Yongbin. (2016). A critical discourse analysis of news reports on Sino-Japan boat collision. International conference on education \& educational research and environmental studies (EERES). ISBN: 978-1-60595-393-9

[3] Clark, R. \& Ivanič, R. (1999). Raising Critical Awareness of Language: A Curriculum Aim for the New Millenium. Language Awareness, Vol. 8, No.2, pp. 63-70.

[4] Fairclough, Norman. (1992). Discourse and socialchange. Cambridge: Polity Press.

[5] Fairclough, Norman. (1995). Critical discourse analysis: The critical research of language. New York: Longman Grup Limited.

[6] Fiske, John. (1990). Introduction to communication studies. Second Edition.London: Routledge.

[7] Fraenkel, J. R., \& Wallen, N. E. (1993). How to design and evaluate research in education. New York: McGraw-Hill, Inc.

[8] Iqbal, A., Danish, M. H. \&Tahir, M. R. (2014a). Exploitation of women in beauty products of Fair and Lovely: A critical discourse analysis study. International Journal on Studies in English Language and Literature. 2(9), 122-131.

[9] Iqbal, A., Danish, M. H. \& Iqbal, F. (2014b). Critical discourse analysis of attributive words used with the word Muslim: A corpus based study. International Journal of Linguistics. 6(4), 1-11. Retrieved from http://dx.doi.org/10.5296/ijl.v6i4.6077.

[10] Jogensen, Marianne W. \& Phillips, Louise J. (2007). Analisis wacana teori dan metode. Yogyakarta: Pustaka Pelajar.

[11] Kaur, K., Arumugam, N. \& Yunus, N. M. (2013). Beauty product advertisements: A critical discourse analysis. Asian Social Science. 9 (3), 61-71.

[12] Lawson, Andrew Joseph. (2008). One-on-one with Obama: An analysis. Centre for English Language Studies. The University of Birmingham.

[13] Mahboob, A. \& Paltridge, B. (2013). Critical Discourse Analysis and Critical Applied Linguistics. Theencyclopedia of applied linguistics. UK: Wiley Blackwell.

[14] Mayasari, M., Darmayanti, N. \& Riyanto, S. (2013). Critical discourse analysis of reportingon "Saweran for KPK Building" in media Indonesia Daily Newspaper. International Journal of Linguistics. 5(4), 213-224.

[15] Muhadjir, N. (2000). Metodologi penelitian kualitatif. $4^{\text {th }}$ edition. Yogyakarta: Rake Sarasin

[16] Mulyana, D. (2001). Metodologi penelitian kualitatif, paradigma baru ilmu komunikasi dan ilmu sosial lainnya. Bandung: Rosdakarya. 
[17] Moleong, L. J. (2002). Metodologi penelitian kualitatif. Bandung: Remaja Rosdakarya.

[18] Pradeep, K. (2016). Analysing Tamil Films with critical discourse analysis approach. International Journal of Linguistics and Computational Applications (IJLCA) Volume 3, Issue 3. ISSN 2394-6385 (Print) ISSN 2394-6393 (Online).

[19] Ramanathan, Renugah \& Hoon, Tan Bee. (2015). Application of critical discourse in media discourse studies. $3 L$ : The Southeast Asian Journal of English Language Studies. Vol 21(2): 57 - 68.

[20] Trianton, Teguh. (2013). Film sebagai media belajar. Yogyakarta: Graha Ilmu.

[21] Vahid, H. \& Esmae'li, S. (2012). The power behind images: Advertisement discourse in focus. International Journal of Linguistics. 4(4), 36-51.

[22] Zhang, M. (2014). A critical discourse analysis of political news report. Theory and practice in language studies. 4(11), 22732277. Retrieved from http:www.ojs.academypublisher.com/ (9/5/2018).

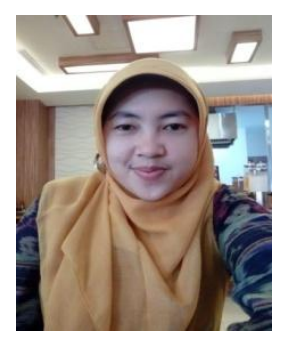

Goziyah. She was born on December 18, 1987. She got her Bachelor's Degree on majoring Program Study of Indonesian Language and Literature Education in University of Sultan Ageng Tirtayasa, Banten, Indonesia, and was graduated on 2009. She took Master Program at the Department of Indonesian Language Education in University of Sultan Ageng Tirtayasa, Banten, Indonesia, and was graduated on 2013, and since on 2015 until now, she is studying in Doctoral Program Language Education, State University of Jakarta, Indonesia.

She was a lecturer at several universities, including the University of Sultan Ageng Tirtayasa, Banten, Indonesia, Falatehan STIKES Indonesia, Indonesia Open University, and Muhammadiyah University of Tangerang, Indonesia. In scientific works, she was produced the acquisition of language in twins "Adlan and Adlin" aged two years and two months (Research of Case Study), published in the journal Cakrawala Bahasa, on 2016. Study of Sociolinguistic Acronyms in English for Indonesian, published in the journal Lingua Rima.

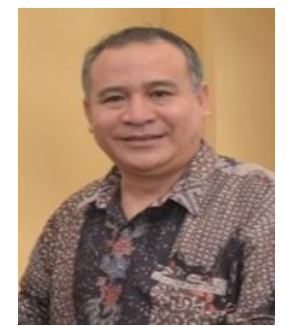

Dadang Sunendar. He was born on October 24, 1963. He got Bachelor Degree's majoring in French Language Education at Indonesia University of Education, Bandung, was graduated on 1987. He was studied Master Program in Literature and Culture in University Indonesia, Depok, Indonesia, was graduated on 1994, and he was studied Doctoral Program in Department of Indonesian Language Teaching in University of Education, Bandung, Indonesia, was graduated on 2001.

He has a strategic position in University of Education, Bandung, Indonesia, that are academic field and non-academic field. He started career as Chair of Departent of Foreign Language Education at Faculty of Education Language and Literature, on 2003-2005, then became Chair of Master Program of French Language Education in Postgraduate Program University of Education, Bandung, Indonesia, on 2005-2008. At the end of 2015, he was appointed as Head of the Development and Coaching Agency by the Minister of Education and Culture of Republic of Indonesia

He has written several scientific works, thats are Etat du francais en Indonesie: une langue a cote a'une ambiance Anglophone. International Journal of Societe Japonaise de Didactique, Japan. Position and Role of Jeanne D'arc in history: Relation to the reflection of the Issues of French Contemporary Women. Historia Accredited National Journal, Department of Hist ory of FPIPS UPI Education.

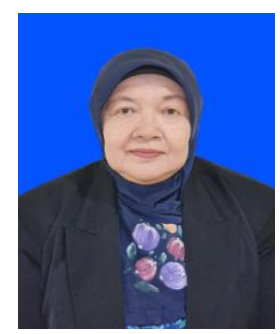

Yumna Rasyid, she was born on March 16, 1951. She was graduated of Language Education for her Master Program and Doctoral Program in State University of Jakarta, Indonesia. She currently as Coordinator of Applied Linguistics for Master Program State University of Jakarta, Indonesia. The scientific work she has written are Error Analysis On The Use Of Letters In Indonesian Written By Thai Student Paper, in Journal Of English Language Studies, 2018. On The Analysis Of Errors In Translation Of Scientific Text From English To Indonesian Language. Jetl (Journal of Education, Teaching And Learning), 2018. 